counterterrorism; disability rights; health; international justice; migrants; press freedom; refugees; terrorism; torture; women's rights.

Address: 350 Fifth Avenue, 34th floor, New York,

NY 10118-3299, USA.

Website: http://www.hrw.org

Executive Director: Kenneth Roth.

\section{Institute for Defence Studies and Analyses (IDSA)}

Founded 1965. Non-partisan, autonomous body funded by the Indian Ministry of Defence that has played a key role in shaping India's foreign and security policies. It aims to promote national and international security by generating and disseminating knowledge on defence and security-related issues.

\author{
Address: 1 Development Enclave, Rao Tula Ram Marg, \\ New Delhi 110010, India. \\ Website: http://www.idsa.in \\ Director General: Jayant Prasad.
}

\section{Institute of World Economy and International Relations}

Founded 1956. Non-profit organization that carries out applied socio-economic, political and strategic research. Research areas include: current global problems; economic theory; economic, social and political problems of the transition period in Russia; forecasting and analysis of world economy dynamics and socio-political developments; international politics; military and strategic problems; theory of international relations; theory of social and political processes.

Address: 23 Profsoyuznaya St., Moscow 117997, Russia.

Website: http://www.imemo.ru

Director: Alexander A. Dynkin.

\section{International Crisis Group}

Founded 1995. Independent, non-profit organization committed to preventing and resolving deadly conflict. Combines fieldbased analysis, policy advice and high-level advocacy to highlight potential future conflicts, resolve peace negotiations and advise governments and intergovernmental bodies.

Address: 149 avenue Louise, Level 24, B-1050 Brussels, Belgium. Website: http://www.crisisgroup.org

President: Jean-Marie Guéhenno.

\section{International Institute for Strategic Studies (IISS)}

Founded 1958. Independent organization, considered the world's leading authority on political-military conflict. Research programme themes: conflict; defence and military analysis; economics and conflict resolution; non-proliferation and disarmament; transnational threats and international political risk; transatlantic dialogue on climate change and security.

Address: Arundel House, 13-15 Arundel St., Temple Place, London WC2R 3DX, UK.

Website: http://www.iiss.org

Director-General: Dr John Chipman.

\section{Japan Institute of International Affairs (JIIA)}

Founded 1959. Private, non-partisan institute committed to research on foreign affairs and security issues. Examines Japanese foreign policy, provides policy recommendations to the government and disseminates information on international relations to the public. JIIA aims to serve as an indispensable resource on international affairs.

Address: 3rd Floor Toranomon Mitsui Building,

3-8-1 Kasumigaseki, Chiyodaku, Tokyo 100-0013, Japan.

Website: http://www2.jiia.or.jp

President: Yoshiji Nogami.

\section{Kiel Institute for the World Economy (Institut für Weltwirtschaft an der Universität Kiel; IfW)}

Founded 1914. Independent, international centre for research in global economic affairs, economic policy consulting, economic education and documentation. Research areas: the global division of labour; knowledge creation and growth; the environment and natural resources; poverty reduction, equity and development; monetary policy under market imperfections; financial markets and macroeconomic activity; reforming the welfare society.

Address: Kiellinie 66, 24105 Kiel, Germany.

Website: http://www.ifw-kiel.de

President: Prof. Dennis Snower.

\section{Konrad Adenauer Foundation (Konrad-Adenauer-Stiftung)}

Founded in 1955 as the Society for Christian Democratic Civic Education and renamed in 1964. Political foundation that focuses on consolidating democracy, the unification of Europe and the strengthening of transatlantic relations, as well as on development co-operation.

Address: Klingelhöferstrasse 23, 10785 Berlin, Germany;

Rathausallee 12, 53757 Sankt Augustin, Germany.

Website: http://www.kas.de

Chairman: Dr Hans-Gert Pöttering.

\section{Korea Development Institute (KDI)}

Founded 1971. Think tank set up by the government aiming to make substantial contributions to the economic and social development of Korea. Research focuses on providing policy recommendations and guidance based on in-depth analyses of international and domestic economic conditions and projections.

Address: 15 Giljae-gil, Sejong, 339-007, South Korea.

Website: http://www.kdi.re.kr

President: Kim Joon-kyung.

\section{Lowy Institute for International Policy}

Founded 2003. Independent think tank that seeks to generate new ideas and dialogue on international developments and Australia's role in the world. Research ranges across all the dimensions of international policy debate in Australia-economic, political and strategic-and is not limited to a particular geographic region.

Address: 31 Bligh St., Sydney, NSW 2000, Australia.

Website: http://www.lowyinstitute.org

Executive Director: Michael Fullilove.

\section{National Bureau of Economic Research (NBER)}

Founded 1920. Private, non-profit, non-partisan research organization dedicated to promoting a greater understanding of how the economy works. Concentrates on four types of empirical research: developing new statistical measurements, estimating quantitative models of economic behaviour, assessing the 